\title{
PENINGKATAN AKTIVITAS DAN KEMAMPUAN MENATA GEBOGAN MELALUI PEMBELAJARAN BERBASIS PROYEK (PROJECT BASED LEARNING) PADA PESERTA DIDIK KELAS XI SMKN 3 DENPASAR TAHUN PELAJARAN 2013/2014 \\ (Finalis Lomba Karya Ilmiah dan Inovasi Pembelajaran Dit PSMK Jakarta)
}

\author{
Oleh \\ Nyoman Aris Suparni \\ SMKN 3 Denpasar \\ suparni.aris@gmail.com
}

\begin{abstract}
ABSTRAK
Penelitian ini bertujuan untuk : (1) Meningkatkan aktivitas belajar peserta didik kelas XI Akomodasi Perhotelan pada pembelajaran Menata Gebogan. sebagai dekorasi ruang melalui pembelajaran berbasis proyek (Project Based Learning). (2) Meningkatkan keterampilan Menata Gebogan sebagai dekorasi ruang pada peserta didik kelas XI Akomodasi Perhotelan melalui pembelajaran berbasis proyek (Project Based Learning)

Subyek penelitian ini adalah peserta didik kelas XI Akomodasi Perhotelan D SMKN 3 Denpasar dengan melibatkan 34 orang, terdiri dari peserta didik laki-laki sebanyak 18 orang dan peserta didik perempuan sebanyak 16 orang. Prosedur penelitian adalah Penelitian Tindakan Kelas (Classroom Action Research) dengan 3 siklus. Data yang dikumpulkan dalam penelitian ini meliputi data aktivitas belajar peserta didik, dengan menggunakan lembar observasi (Check-List) dan data hasil belajar peserta didik terhadap penerapan pembelajaran berbasis proyek dalam kompetensi Menata Gebogan dengan menggunakan penilaian autentik. Data aktivitas dan hasil belajar peserta didik dianalisis dengan statistik deskriptif

Hasil penelian ini menunjukkan bahwa aktivitas peserta didik pada pelajaran menata gebogan melalui Project Based Learning terjadi peningkatan secara signifikan pada siklus1,siklus 2 dan siklus 3. Peningkatan tersebut meliputi peningkatan aktivitas dan hasil belajar peserta didik. Pada siklus 1 menunjukan bahwa ketuntasan belajar peserta didik sebesar 73,52\% dan aktivitas ada pada kategori kurang aktif. Pada siklus 2 menunjukan bahwa ketuntasan belajar peserta didik sebesar $76,47 \%$ dan aktivitas ada pada kategori cukup aktif. Dan pada siklus 3 menunjukan bahwa ketuntasan belajar peserta didik sebesar $100 \%$ dan aktivitas ada pada kategori sangat aktif.
\end{abstract}

Kata-kata kunci: Pembelajaran berbasis proyek (Project Based Learning), Aktivitas, Keterampilan.

\begin{abstract}
This research has the purposes to: 1) improve the learning activities of grade XI students of Hotel Accommodation Department in the subject of "Menata Gebogan" (Arranging Gebogan) as room decorations through project based learning, 2) Enhancing the skills of grade XI students of Hotel Accommodation Department in using Gebogan arrangement as room decorations through project based learning.

The subject of the research is grade XI-D of Hotel Accommodation Department of SMKN 3 Denpasar which involves 34 students, 18 of them are males and 16 are females. The research procedure is the 3-cycle classroom action research. The data obtained in this research include the data of student's learning activities by using observation check-list and the data of student's learning outcomes by applying project-based learning for the
\end{abstract}


competency of arranging gebogan with authentic assessment. Both kinds of data above are analyzed by descriptive statistic means.

The result of this research reveals that the student's activities during the lessons of arranging gebogan through project-based learning increased significantly during the $1^{\text {st }}$, $2^{\text {nd }}$ and $3^{\text {rd }}$ cycles. The increase involved both the activity and the learning outcomes of the students. The $1^{\text {st }}$ cycle indicates that student's learning achievement is $73.52 \%$ while the categorization of activity is still in low level. The $2^{\text {nd }}$ cycle shows the student's learning achievement reached $76.47 \%$ while the student's activity reached a higher level or middle category. Finally, the $3^{\text {rd }}$ cycle shows that the student's achievement has reached the maximum of $100 \%$ and the student's activity can be categorized into a level of very high.

Keywords: Project-based learning, activity and skill.

\section{PENDAHULUAN}

Kelompok mata pelajaran Kompetensi Kejuruan merupakan pelajaran yang memiliki arti sangat penting pada Sekolah Menengah Kejuruan (SMK) sebab karakteristik kompetensi ini diarahkan untuk membekali peserta didik agar memiliki kompetensi kerja sesuai dengan Standar Kompetensi Kerja Nasional Indonesia (SKKNI). Hal ini sesuai dengan misi sekolah menengah kejuruan yaitu: (1) menyiapkan tenaga kerja (tamatan SMK) untuk mengisi keperluan pembangunan., (2) menciptakan tenaga kerja yang berkualitas professional sehingga mampu berperan sebagai factor keunggulan bagi industry Indonesia., (3) Menghasilkan tamatan yang mampu mandiri, mampu member bekal profesi untuk meningkatkan martabat dirinya., (4) mengubah status beban menjadi asset., serta (5) memberi bekal kepada tamatan sehingga mampu mengembangkan kualitas dirinya secara berkelanjutan. (Ditdikmenjur,1997:29). Salah satu mata pelajaran dimaksud adalah menyediakan ruang rapat/seminar (function room) dan salah satu sub kompetensinya adalah menata gebogan sebagai dekorasi ruang. Kompetensi ini memiliki dua aspek sasaran yang harus dicapai yaitu peserta didik terampil dalam menata gebogan serta mampu menumbuhkan sikap enterpreneur/wirausaha khususnya dalam usaha membuat gebogan sebagai dekorasi ruang.

Untuk dapat menguasai kompetensi menata gebogan sebagai dekorasi ruang dalam proses pembelajaran banyak masalah yang ditemukan. Dari pengalaman mengajar di kelas XI Akomodasi Perhotelan D(yang selanjutnya disingkat APD) diperoleh ganbaran bahwa : (1) masih sulit melibatkan peserta didik untuk belajar aktif. Peserta didik cenderung menerima apa yang dijelaskan guru dan tidak ada usaha kreatif untuk mengembangkan dan bertanya jika ada hal yang belum dipahami sehingga pada pembelajaran berikutnya guru harus menjelaskan kembali apa yang telah dipelajari sebelumnya. (2) peserta didik belum terbiasa bekerja secara kelompok dan lebih sering 
belajar secara individu, hal ini mengakibatkan kurang terlaksananya keterampilan social pada kelas tersebut. Situasi ini berdampak pada rendahnya aktivitas peserta didik. (3) keterampilan peserta didik dalam menemukan ide/gagasan/desain dalam menata gebogan sebagai dekorasi ruang sangat kurang, ketika melaksanakan kegiatan praktik terkesan seadanya saja tanpa konsep, sehingga hasil belajar yang dicapai kurang optimal. Dari dampak tersebut menyebabkan dampak lebih lanjut yaitu rendahnya hasil belajar peserta didik di kelas tersebut. Hal ini dapat dilihat dari perolehan nilai peserta didik, daya serap dan Kriteria Ketuntasan Belajar (KKM) peserta didik kelas XI AP D yang disajikan pada Tabel 1 berikut:

Tabel 1.Data Hasil Belajar Menata Gebogan Peserta Didik Kelas XI AP D SMKN 3 Denpasar tahun Pelajaran 2013/2014

\begin{tabular}{|l|l|l|l|l|}
\hline $\begin{array}{l}\text { Jumlah Peseta } \\
\text { didik }\end{array}$ & KKM & Rata-Rata & $\begin{array}{l}\text { Daya Serap } \\
(\%)\end{array}$ & KetuntasanBelajar \\
\hline 5 & 80 & 65 & $14,70 \%$ & TT/TK \\
\hline 8 & 80 & 70 & $23,53 \%$ & TT/TK \\
\hline 3 & 80 & 75 & $8,82 \%$ & TT/TK \\
\hline 10 & 80 & 80 & $29,42 \%$ & T/K \\
\hline 5 & 80 & 85 & $14,8 \%$ & T/K \\
\hline 3 & 80 & 90 & $8,82 \%$ & T/K \\
\hline$\Sigma \mathrm{N}=34$ & 80 & 76,62 & $100 \%$ & $52,95 \%$ \\
\hline
\end{tabular}

Dari analisis terhadap perolehan hasil belajar peserta didik menunjukan bahwa 47,05\% (16 org) diposisi tidak tuntas/tidak kompeten (TT/TK) dan 52,95\% (18 org) ada pada kategori tuntas/kompeten(T/K). hal ini berarti ketuntasan belajar klasikal minimal $80 \%$ (27 org) belum terpenuhi, sementara ketuntasan individu (mastery learning) juga tidak terpenuhi karena ketuntasan individu mengisyaratkan bahwa semua peserta didik harus tuntas dengan memperoleh nilai minimal 80 sesuai KKM, tapi ternyata 47,05 \% (16 org)dari 34 peserta didik hasil belajarnya belum tuntas.

Setelah dianalisis ternyata kekurang berhasilan ini disebabkan oleh banyak faktor. Salah satu factor penyebabnya adalah terbatasnya waktu praktik di sekolah. Disamping itu peserta didik belum mendapat keleluasaan untuk belajar dengan mengefektifkan masyarakat dan lingkungan sebagai sumber belajar. Menyadari banyak faktor yang menjadi penyebab kekurang berhasilan ini maka perlu dikaji factor utama yang memungkinkan sebagai penyebab kesulitan belajar peserta didik. Berbagai upaya telah dilakukan untuk memperbaiki proses pembelajaran seperti memperpanjang waktu praktik serta merubah cara penyampaian materi namun belum menunjukan hasil yang optimal terutama dalam keterampilan menata gebogan ukuran besar. Berdasarkan kenyataan tersebut perlu dicarikan alternatif lainnya dengan melakukan inovasi pembelajaran. Untuk 
meningkatkan pengetahuan dapat dilakukan dengan pengkajian berbagai sumber belajar seperti literature, memanfaatkan media internet atau sumber belajar lainnya. Sedangkan peningkatan keterampilan perlu adanya kegiatan praktik pada DU/DI, maupun usaha rumahan sehingga peserta didik dapat melakukan praktik secara efektif karena pelatihan dilakukan di tempat usaha sesungguhnya.

Berdasarkan kondisi tersebut, penulis mengadakan penelitian Peningkatan Aktivitas dan Keterampilan Menata Gebogan Melalui Pembelajaran Berbasis Proyek (Project Based Learning) pada Peserta Didik Kelas XI AP D SMKN 3 Denpasar Tahun Pelajaran 2013./2014.

\section{METODE PENELITIAN}

Prosedur penelitian yang dilakukan adalah Penelitian Tindakan Kelas (Classroom action Research) yang terdiri dari 3 siklus. Tiap siklus dilaksanakan sesuai dengan strategi pengorganisasian pembelajaran dengan perubahan yang dicapai, dengan cara melihat hasil observasi, evaluasi tindakan, refleksi dan dilakukan identifikasi kekurangan tindakan siklus 1. Evaluasi hasil siklus 1 dilanjutkan ke siklus 2 dengan berpatokan pada refleksi siklus 1 , demikian setrusnya sampai siklus 3. Penelitian tindakan ini mengikuti model Kemmis dan Mc. Taggart dengan prosedur : (1) refleksi awal, (2) tahap perencanaan, (3) tahap pelaksanaan tindakan, (4) tahap observasi dan evaluasi serta (5) tahap refleksi.

Subyek penelitian ini adalah peserta didik kelas XI AP D SMKN 3 Denpasar dengan melibatkan 34 orang, terdiri dari peserta didik laki-laki sebanyak 18 orang dan peserta didik perempuan sebanyak 16 orang

Data yang dikumpulkan dalam penelitian ini meliputi data aktivitas belajar dan data hasil belajar peserta didik. Metode dan alat pengumpulan data disaikan dalam table 2 berikut:

Tabel 2. Metode dan Alat Pengumpulan Data

\begin{tabular}{|l|l|l|l|l|}
\hline No & Jenis Data & Metode & Alat Pengumpulan Data & Sumber Data \\
\hline 1 & Aktivitas & Observasi & $\begin{array}{l}\text { Lembar Observasi (Check } \\
\text { List) } \\
\text { (Rating-Scale) dengan 6erta didik, } \\
\text { indikator }\end{array}$ & Pembimbing \\
\hline 2 & $\begin{array}{l}\text { Hasil } \\
\text { Belajar }\end{array}$ & Penugasan/Proyek & $\begin{array}{l}\text { Penilaian autentik ( } \\
\text { Penilaian Peserta didik } \\
\text { Kinerja, Kulminasi, sikap, } \\
\text { dan Laporan) }\end{array}$ & \\
\hline
\end{tabular}

JPTK, UNDIKSHA, Vol. 13, No. 1, Januari 2016 : 23 - 34 
Hasil observasi aktivitas peserta didik dianalisis dengan statistic deskriptif. Kriteria penggolongan aktivitas peserta didik didasarkan pada skor rata-rata Aktivitas peserta didik $(\bar{A})$, mean ideal (MI), Standar Deviasi ideal (SDI) yaitu :

$$
\begin{aligned}
& \mathrm{MI}=\frac{1}{2}(\text { skor tertinggi ideal }+ \text { skor terendah ideal }) \\
& \mathrm{SDI}=\frac{1}{6}(\text { skor tertinggi ideal }- \text { skor terendah ideal })
\end{aligned}
$$

Penggolongan mengenai aktivitas belajar peserta didik secara klasikal menggunakan kriteria sebagai berikut.

Tabel 3 : Penggolongan dan kriteria aktivitas peserta didik

\begin{tabular}{|c|r|l|}
\hline Interval & & \multicolumn{1}{|c|}{ Kriteria } \\
\hline $\mathrm{MI}+1.5 \mathrm{SDI} \leq \bar{A}$ & $\rightarrow$ & Sangat aktif \\
\hline $\mathrm{MI}+0.5 \mathrm{SDI} \leq \bar{A}<\mathrm{MI}+1.5 \mathrm{SDI}$ & $\rightarrow$ & Aktif \\
\hline $\mathrm{MI}-0.5 \mathrm{SDI} \leq \bar{A}<\mathrm{MI}+0.5 \mathrm{SDI}$ & $\rightarrow$ & Cukup aktif \\
\hline $\mathrm{MI}-1.5 \mathrm{SDI} \leq \bar{A}<\mathrm{MI}-0.5 \mathrm{SDI}$ & $\rightarrow$ & Kurang aktif \\
\hline $\bar{A}<\mathrm{MI}-1.5 \mathrm{SDI}$ & $\rightarrow$ & Sangat kurang aktif \\
\hline
\end{tabular}

Skor rata-rata aktivitas pada ke-enam indikator aktivitas peserta didik dihitung dengan rumus:

$$
\bar{A}=\frac{\sum_{i=1}^{n} A_{i}}{N}
$$

Keterangan:

$$
\begin{array}{ll}
\bar{A} & =\text { skor rata-rata aktivitas peserta didik } \\
\sum A_{i} & =\text { jumlah skor tiap peserta didik } \\
N & =\text { banyak peserta didik yang diteliti }
\end{array}
$$

(Nurkancana, Sunartana, 1992)

Hasil belajar peserta didik dianalisis secara deskriptif, yaitu dengan menggunakan skor rata-rata hasil belajar $(\bar{X})$ dengan rumus:

$$
\bar{X}=\frac{\sum_{i=1}^{n} X_{i}}{N}
$$


Keterangan :

$$
\begin{array}{ll}
\bar{X} & =\text { skor rata-rata hasil belajar } \\
\sum X_{i} & =\text { jumlah skor tes hasil belajar peserta didik } \\
N \quad & =\text { banyak peserta didik yang diteliti }
\end{array}
$$

(Nurkancana dan Sunartana, 1992)

Selain itu akan dilihat pula tentang ketuntasan belajar (KB) dan daya serap (DS) serta ketuntasan Materi (KM). Analisis tentang kriteria ketuntasan minimal (KKM) dan daya serap (DS) serta ketuntasan materi (KM) dilakukan sebagai berikut.

$$
\begin{aligned}
& \mathrm{KB}=\frac{\text { banyaknya siswa yang memperoleh skor } \geq 80}{N} \times 100 \% \\
& \mathrm{DS}=\bar{X} \times 100 \% \\
& \mathrm{KM}=M i / M
\end{aligned}
$$

Keterangan:

$$
\begin{aligned}
\mathrm{KB}= & \text { ketuntasan belajar } \\
\mathrm{DS}= & \text { daya serap } \\
\mathrm{KM}= & \text { ketuntasan materi } \\
M i= & \text { materi yang bisa terselesaikan dalam waktu yang telah } \\
& \text { ditentukan } \\
M \quad= & \text { materi yang bisa terselesaikan sampai batas waktu yang } \\
& \text { Disediakan } \\
\bar{X}= & \text { skor rata-rata hasil belajar }
\end{aligned}
$$

Pedoman yang digunakan untuk melakukan interpretasi terhadap data tentang hasil belajar secara klasikal menurut Depdikbud (1994) adalah tercapainya Ketuntasan belajar $80 \%$, daya serap minimal 80\%, dan kriteria ketuntasan minimal (KKM) $80 \%$ serta ketuntasan materi $100 \%$.

Secara keseluruhan penelitian ini dikatakan berhasil apabila aktivitas belajar peserta didik mengalami peningkatan baik itu dari tahap refleksi awal maupun dari siklus sebelumnya dan harus memenuhi kriteria yang ditetapkan. Aktivitas belajar peserta didik pada akhir siklus ke 3 minimal pada kriteria aktif. Hasil belajar yang diperoleh harus meningkat dari siklus sebelumnya dan pada akhir siklus tercapainya rata-rata kelas minimal 80, daya serap minimal $80 \%$, dan kriteria ketuntasan minimal $80 \%$.

JPTK, UNDIKSHA, Vol. 13, No. 1, Januari 2016 : 23 - 34 


\section{HASIL DAN PEMBAHASAN}

\section{a. Hasil}

Berdasarkan hasil perhitungan, maka rata-rata aktivitas peserta didik dari siklus 1, siklus 2 dan siklus 3 adalah sebagai berikut.

Tabel 4 : Rata-rata Aktivitas Peserta Didik Siklus 1

\begin{tabular}{|c|c|l|}
\hline Interval & & \multicolumn{1}{|c|}{ Kriteria } \\
\hline $24,00 \leq 13,29$ & $\rightarrow$ & Sangat aktif \\
\hline $20,00 \leq 13,29<24,00$ & $\rightarrow$ & Aktif \\
\hline $16,00 \leq 13,29<20,00$ & $\rightarrow$ & Cukup aktif \\
\hline $\mathbf{1 2 , 0 0} \leq \mathbf{1 3 , 2 9}<\mathbf{1 6 , 0 0}$ & $\rightarrow$ & Kurang aktif \\
\hline $13,29<12,00$ & $\rightarrow$ & Sangat kurang aktif \\
\hline
\end{tabular}

Data tentang hasil belajar peserta didik dalam pembelajaran berbasis proyek (project based learning) pada siklus I menunjukkan bahwa skor tertinggi yang dicapai peserta didik adalah 100,00 dari skor maksimal yang mungkin bisa dicapai yaitu 100,00. Sedangkan skor terendah yang dicapai peserta didik adalah 70,00 dari skor minimal yang mungkin terjadi yaitu 0,00. Ketuntasan belajar peserta didik yang dicapai 73,529\%, Daya serap 83,386\% dan ketuntasan materi $100 \%$. Sementara kriteria ketuntasan minimal adalah 80. Perhitungan hasil belajar siswa siklus I dapat disajikan sebagai berikut.

a. $\mathrm{KB}=\frac{\text { banyaknya siswa yang memperoleh skor } \geq 80}{N} \times 100 \%$

$$
=\frac{25}{34} X 100 \%=\mathbf{7 3 , 5 2 9 \%}
$$

b. $\mathrm{DS}=\bar{X} \times 100 \%$

$$
=\frac{2.835}{34}=83,39 \%
$$

c. $\mathrm{KM}=\mathrm{Mi} / \mathrm{M}$

$$
=1 / 1 \times 100 \%=100 \%
$$

Tabel 4 : Rata-rata Aktivitas Peserta Didik Siklus 2

\begin{tabular}{|c|c|l|}
\hline Interval & & \multicolumn{2}{|c|}{ Kriteria } \\
\hline $24,00 \leq 17,41$ & $\rightarrow$ & Sangat aktif \\
\hline $20,00 \leq 17,41<24,00$ & $\rightarrow$ & Aktif \\
\hline $\mathbf{1 6 , 0 0} \leq \mathbf{1 7 , 4 1}<\mathbf{2 0 , 0 0}$ & $\rightarrow$ & Cukup aktif \\
\hline $12,00 \quad \leq 17,41<16,00$ & $\rightarrow$ & Kurang aktif \\
\hline $17,41<12,00$ & $\rightarrow$ & Sangat kurang aktif \\
\hline
\end{tabular}


Data tentang hasil belajar peserta didik dalam pembelajaran berbasis proyek (project work) pada siklus 2 menunjukkan bahwa skor tertinggi yang dicapai peserta didik adalah 100,00 dari skor maksimal yang mungkin bisa dicapai yaitu 100,00. Sedangkan skor terendah yang dicapai peserta didik adalah 75,00 dari skor minimal yang mungkin terjadi yaitu 0,00. Keteuntasan belajar peserta didik yang dicapai 76,47\%, Daya serap $86,03 \%$ dan ketuntasan materi 100\%. Sementara kriteria ketuntasan minimal adalah 80. Perhitungan hasil belajar peserta didik pada siklus 2 adalah sebagai berikut.

$$
\begin{aligned}
\text { a. } \mathrm{KB} & =\frac{\text { banyaknya siswa yang memperoleh skor } \geq 80}{N} \times 100 \% \\
& =\frac{26}{34} \times 100 \%-=\mathbf{7 6 , 4 7 \%} \\
\text { b. } \quad \mathrm{DS} & =\bar{X} \times 100 \% \\
& =\frac{2925}{34} \times 100 \%=86,03 \% \\
\text { c. } \quad \mathrm{KM} & =M i / M \\
& =\frac{1}{1} \times 100 \%=100 \%
\end{aligned}
$$

Tabel 5 : Rata-rata Aktivitas Peserta Didik Siklus 3

\begin{tabular}{|c|c|l|}
\hline Interval & & \multicolumn{2}{|c|}{ Kriteria } \\
\hline $\mathbf{2 4 , 0 0} \leq \mathbf{2 5 , 5 3}$ & $\rightarrow$ & Sangat aktif \\
\hline $20,00 \leq 25,53<24,00$ & $\rightarrow$ & Aktif \\
\hline $16,00 \leq 25,53<20,00$ & $\rightarrow$ & Cukup aktif \\
\hline $12,00 \leq 25,53<16,00$ & $\rightarrow$ & Kurang aktif \\
\hline $25,53<12,00$ & $\rightarrow$ & Sangat kurang aktif \\
\hline
\end{tabular}

Data tentang hasil belajar peserta didik dalam pembelajaran berbasis proyek (project based learning) pada siklus 3 menunjukkan bahwa skor tertinggi yang dicapai peserta didik adalah 100,00 dari skor maksimal yang mungkin bisa dicapai yaitu 100,00. Sedangkan skor terendah yang dicapai peserta didik adalah 90,00 dari skor minimal yang mungkin terjadi yaitu 0,00. Keteuntasan belajar peserta didik yang dicapai 100,00\%, Daya serap 93,97\% dan ketuntasan materi 100\%. Sementara kriteria ketuntasan minimal adalah 80. Perhitungan hasil belajar peserta didik pada siklus 3 adalah sebagai berikut.

$$
\text { a. } \begin{aligned}
\mathrm{KB} & =\frac{\text { banyaknya siswa yang memperoleh skor } \geq 80}{N} \times 100 \% \\
& =\frac{34}{34} \times 100 \%=\mathbf{1 0 0 , 0 0 \%}
\end{aligned}
$$

JPTK, UNDIKSHA, Vol. 13, No. 1, Januari 2016 : 23 - 34 


$$
\begin{aligned}
& \text { b. } \quad \mathrm{DS}=\bar{X} \times 100 \% \\
& =\frac{3195}{34} \times 100 \%=93,97 \% \\
& \text { c. } \mathrm{KM}=M i / M \\
& =\frac{1}{1} \times 100 \%=100 \%
\end{aligned}
$$

\section{b. Pembahasan}

Hasil perhitungan keterampilan peserta didik pada siklus 1 keterampilan peserta didik yaitu ketuntasan belajar sebesar 73,52\%, daya serap 83,39\% ketuntasan materi 100,00\% dari kriteria ketuntasan minimal 80. Dari 34 peserta didik subjek penelitian, 3 peserta didik $(8,82 \%)$ memperoleh skor $70 ; 6$ peserta didik $(17,65 \%)$ memperoleh skor $75 ; 8$ peserta didik $(23,53 \%)$ memperoleh skor $80 ; 7$ peserta didik $(20,59 \%)$ memperoleh skor $85 ; 7$ peserta didik (20,59\%) memperoleh skor 90 dan 3 peserta didik $(8,82 \%)$ memperoleh skor 100.Untuk aktivitas peserta didik pada siklus 1 ada pada kategori kurang aktif. Jika dirinci maka : 8 peserta didik (23,53\%) ada pada kategori aktif, 5 peserta didik (14,71\%) cukup aktif, 5 peserta didik (14,71\%)kurang aktif dan 16 peserta didik (47,06\%) ada pada kategori sangat kurang aktif.

Pada tindakan siklus I masalah yang perlu diperbaiki yaitu pada aspek memberikan keleluasaan berkreasi dan berinovasi dengan kegiatan : (1)membentuk kelompok belajar peserta didik yang lebih kecil dengan kemampuan akademik yang bersifat heterogen dengan anggota 3 orang dengan maksud agar lebih mudah dalam memberikan pengawasan pada masing-masing kelompok belajar, (2) guru merancang dan membuat kartu bimbingan untuk mengontrol kerja peserta didik, (3) memberi alokasi waktu yang lebih banyak pada saat kegiatan praktik atau menyelesaikan proyek, (4) menyiapkan sumber belajar yang lebih komplek dan beragam serta pendukung belajar tidak dibatasi agar peserta didik dapat mengekplor pengetahuan, keterampilan dan sikap pada materi menata gebogan.

Pada tes tindakan/siklus 2, pembentukan kelompok dirubah menjadi kelompok lebih kecil yaitu 3 orang.di lakukan dengan mengubah cara pemberian tugas melalui tugas kelompok yang dikerjakan di rumah dengan mengambil sumber belajar baik dari buku, perpustakaan, internet maupun lingkungan. Tugas pada siklus satu, kurang efektif sebab durasi waktu yang diberikan hanya 3 jam pelajaran (3x45 menit), hal ini menyebabkan daya dukung pembelajaran terbatas pada fasilitas yang ada dikelas saja. Sementara pada siklus 2 waktu, sumber belajar, dan pendukung belajar yang lain diperpanjang namun tetap ditentukan sehingga memungkinkan peserta didik dapat lebih mengeksplor 
pengetahuan yang dimilikinya dengan fasilitas belajar yang lebih kompleks dan beragam yang tersedia di sekolah, hal ini diduga kuat akan memberikan kesempatan kepada semua peserta didik untuk mengeluarkan potensi yang dimilikinya melalui tugas yang diberikan oleh guru sehingga peserta didik pada saat presentasi lebih banyak dapat mempersiapkan diri yang berdampak pula pada meningkatnya kepercayaan diri pada saat bertanya maupun menjawab pertanyaan peserta didik lain. Hasil yang diperoleh pada siklus 2 adalah $76,47 \%$ peserta didik tuntas dalam belajar, daya serap $86,04 \%$ dan ketuntasan materi100\% .Untuk aktivitas belajar peserta didik ada peningkatan yaitu : rata-rata kategori peserta didik meningkat pada kategori cukup aktif dan jika dijabarkan maka 7 peserta didik $(23,53 \%)$ pada kategori sangat aktif, 10 peserta didik $(29,41 \%)$ pada kategori aktif, 10 peserta didik $(29,41 \%)$ kurang aktif, 7 peserta didik $(23,53 \%)$ sangat kurang aktif.

Dari perolehan skor hasil belajar, aktivitas peserta didik pada siklus 2 sudah terjadi peningkatan tapi belum optimal. Dengan demikian perlu perbaikan pada tindakan siklus 3. Pada tindakan siklus 2 masalah yang perlu diperbaiki yaitu dengan merencanakan program pembelajaran yang lebih bebas tetapi terarah dari segi waktu diperpanjang, sumber belajar diperluas, dan pendukung belajar . Rencana belajar akan dilakukan didua tempat yaitu di Sekolah dan di dunia usaha atau dunia industri (DU/DI) maupun usaha rumahan yang ada di masyarakat. Dengan memberikan peserta didik belajar dengan sumber belajar yang ada baik di Sekolah maupun DU/DI maka memungkinkan peserta didik dapat mengeksplor pengetahuan yang dimilikinya dengan fasilitas belajar yang lebih kompleks dan beragam, hal ini diduga kuat akan memberikan kesempatan kepada semua peserta didik untuk mengeluarkan potensi yang dimilikinya melalui tugas yang diberikan oleh guru sehingga peserta didik pada saat presentasi lebih banyak dapat mempersiapkan diri yang berdampak pula pada munculnya kepercayaan diri peserta didik untuk menuangkan ide, gagasan, bertanya maupun menjawab pertanyaan peserta didik lain. Sementara dalam kegiatan praktek, peserta didik semakin antusias karena mendapat keleluasaan waktu dan kesempatan latihan lebih banyak.

Langkah nyata yang dilakukan adalah mulai dari membentuk kelompok kerja (3 orang), menentukan judul proyek, membuat proposal project work, implementasi di masyarakat pada industri rumahan, maupun DU/DI. Pada saat melakukan tugas proyek di lapangan guru melakukan observasi secara berkala di tempat peserta didik magang dan mengisi kartu bimbingan bersama pembimbing di industri. Dalam waktu yang telah ditentukan peserta didik mempresentasikan hasil kerjanya, dengan mengundang penilai 1

JPTK, UNDIKSHA, Vol. 13, No. 1, Januari 2016 : 23 - 34 
dari asosiasi profesi dan penilai 2 dari guru dengan menggunakan penilaian autentik. Setelah selesai peserta didik membuat laporan.

Hasil yang diperoleh pada siklus 3 adalah $100 \%$ peserta didik telah tuntas dalam belajar, daya serap $93,97 \%$ dan ketuntasan materi $100 \%$ telah tuntas dalam pelajaran menata gebogan sebagai dekorasi ruang.

Untuk aktivitas belajar peserta didik pada siklus 3 ada pada sangat aktif dan jika dijabarkan maka 26 peserta didik $(85,29 \%)$ pada kategori sangat aktif, dan 8 peserta didik $(23,53 \%)$ pada kategori aktif.

\section{PENUTUP}

Dari hasil analisis data dan pembahasan tersebut maka:

1) Dengan model pembelajaran berbasis proyek (project based learning) dalam kompetensi menata gebogan sebagai dekorasi ruangternyata dapat meningkatkan hasil belajar peserta didik secara signifikan.

2) Aktivitas belajar peserta didik meningkat karena pemberian tugas proyek dapat memberi keleluasaan peserta didik menemukan dan mengeksplor informasi, fakta, konsep dan prosedur sehingga pembelajaran lebih bermakna.

3) Dengan memberikan peserta didik melakukan tugas proyek di Lapangan (masyarakat/DUDI) peserta didik dapat lebih bersosialisasi pada lingkungan, menggunakan sumber belajar yang lebih banyak seperti buku, perpustakaan, internet maupun lingkungan, ternyata hasil belajar peserta didik, keaktivan peserta didik terhadap kompetensi menata gebogan sebagai dekorasi ruang dapat meningkat secara signifikan.

Dengan demikian, maka dapat disimpulkan bahwa kegiatan pembelajaran berbasis proyek (project based learning) dapat meningkatkan aktivitas dan hasil belajar peserta didik. Hal ini sejalan dengan pendapat dari Daryanto (2009), Usman (1995) dan Sriyono (2001) yang mengatakan bahwa keaktivan belajar peserta didik menyebabkan suasana belajar menjadi lebih kondusif sehingga dapat memaknai pembelajaran tersebut. Keaktivan yang tinggi dapat mempengaruhi hasil belajarnya. Dengan memberikan peserta didik pengalaman belajar dalam kehidupan nyata di lapangan melalui pembelajaran berbasis proyek maka kreativitas dan motivasi peserta didik dapat meningkat. Dengan meningkatnya aktivitas, kreativitas dan motivasi peserta didik dalam proses pembelajaran akan dapat meningkatkan hasil belajarnya.

Berdasarkan hasil penelitian tersebut maka penggunaan pembelajaran berbasis proyek (project based learning) dapat diterapkan pada kompetensi menata gebogan 
sebagai dekorasi ruang karena dapat meningkatkan hasil belajar secara optimal. Sebelum pembelajaran dimulai terlebih dahulu melakukan identifikasi awal tentang kelemahan (permasalahan) dalam pembelajaran sehingga dapat diterapkan metode dan strategi pembelajaran yang tepat. Mengingat penggunaan pembelajaran berbasis proyek (project based learning) ini apabila dilaksanakan dengan baik akan mampu meningkatkan aktivitas, dan hasil belajar peserta didik, maka perlu diterapkan pada setiap mata pelajaran khususnya kompetensi menata gebogan sebagai dekorasi ruang.

\section{DAFTAR PUSTAKA}

Daryanto,2009. Panduan Proses Pembelajaran Kreatif dan Inovatif. Jakarta : AV Publisher.

Dikmenjur,1997.Makalah

Kemmis, Stephen \& Taggrat, Robin Mc.1998. The Action Research Planner. Victoria: Deakin University.

Nurkancana, Wayan dan Sunartana.1992. Evaluasi Hasil Belajar. Surabaya Penerbit Usaha Nasional.

Sriyono.1991. Teknik Belajar Mengajar Dalam CBSA. Jakarta. PT. Melton Putra

Usman, Moh. Uzer.1995.Menjadi Guru Profesional. Bandung : PT Remaja Rosdakarya. 